\section{CULTURAL HISTORY AS POLYPHONIC HISTORY}

\author{
Peter Burke \\ University of Cambridge
}

\begin{abstract}
RESUMEN: En este texto se ofrece una reflexión sobre el origen y actual desarrollo del campo de la historia cultural a través de una comparación con el término que ha dado título a este seminario: "historia polifónica". El autor propone un recorrido por las áreas temáticas que han conformado la estructura del seminario (la historia de las representaciones, la historia del cuerpo y la historia cultural de la ciencia) con el objeto de explicitar y explicar esta pluralidad de voces en el campo de la historia, así como su repercusión en otras áreas del conocimiento.
\end{abstract}

PALABRAS CLAVE: Historia cultural; giro cultural; historia polifónica.

The occasion of the conference that led to this special issue was a moving one for me. I am deeply grateful to the organizers and contributors for making the event happen and was delighted by the conference itself, including its title, a welcome sign of the increasing interest in Bakhtin on the part of historians: in the whole Bakhtin rather than the author of an exciting but sometimes questionable book on Carnival (Mantecón, 2008).

In France, the final speaker might reasonably be expected to summarize the collective conclusions of the earlier participants. Fortunately for me, Madrid is very different from Paris, leaving me free to adopt a more individualistic approach, commenting on a few central themes of this wideranging conference, beginning with the idea of polyphonic history itself.

What is polyphonic history? It might be useful to begin by defining it negatively, in opposition to historical "monody". It is polyglot rather than monoglot, presented as dialogue rather than monologue, and tells multiple stories rather than a single Grand Narrative. One of the great changes in the humanities in the last half-century has been the multiplication of the voices expressed in texts, or to switch from an aural to a visual metaphor, the multiplication of perspectives or points of view, in

\section{HISTORIA CULTURAL COMO HISTORIA POLIFÓNICA}

ABSTRACT: This texts offers a reflection on the origins and actual development of the field of cultural history through a comparison with the term that has served as title for this seminar: "polyphonic history". The author provides an overview of the themes that have structured the seminar (the history of representations, the history of the body and the cultural history of science) with the aim of making explicit and clarifying this plurality of voices in the field of history as well as its pervasiveness in other research areas.

KEY WORDS: Cultural history; cultural turn; polyphonic history.

anthropology, sociology, literature and other disciplines as well as in history.

It may be useful to distinguish between various forms of polyphonic history. One variety might be defined by the concern with "perspectivism", with the plurality of viewpoints that existed in the past. Thus Miguel León Portilla (1961) and Nathan Wachtel (1971) have been concerned to reconstruct what they call the "vision of the vanquished", the attitudes of the Indians of Mexico and Peru after the Spanish conquest. In similar fashion, the scholars involved in the British movement for "history from below" and the Indian movement for "subaltern studies" have made ordinary people - and their view of society - visible, while feminist historians have done the same for women.

Here, following the master metaphor of the conference, let us describe this kind of history as concerned to make audible the multiple voices of the past, the working classes as well as the middle classes, losers as well as winners, victims as well as aggressors, in short the "Cinderellas of history" [Os marias-borralheiras da história], to use the memorable phrase of the Brazilian Gilberto Freyre (1948, $50)$, as well as its normal heroes. In the last decades, historical writing on cultural encounters and also desencuentros - to use the expressive Spanish term which 
unfortunately lacks an English equivalent - has multiplied at a rate that is as gratifying as it is terrifying.

The phrase "polyphonic history" may also be employed to refer to the plurality of approaches to the past that exist at the present time, in which, to quote the Chinese saying (which Mao Zedong notoriously misused in order to trap his opponents) "Let 100 flowers bloom, let 100 schools of thought contend".

Micro-historians and macro-historians, scholars concerned with "high" and "low" politics, economic historians and historians of the environment, historians of the body and historians of mentalities, as well as "old" and "new" cultural historians (to say nothing of historians of art, literature and science, who usually inhabit other departments on the campus) now coexist, more or less happily, in the university.

Many of these different approaches depend on regular conversations between historians and scholars in other disciplines, so we might use the phrase "polyphonic history", as I believe Manuel Lucena Giraldo and Javier Moscoso intended, to refer to historical writing that draws on other disciplines - not only anthropology, sociology, and the history of art and literature, science and philosophy but also, as contributions to this conference made clear, neuroscience and "cultural zoology" - for chimpanzees, for instance, have a culture in the sense that they not only learn from experience but pass on what they have learned (Wrangham, 1994).

A substantial proportion of historical writing now attempts to follow this ideal, so that we might describe our time as marked by a "polyphonization" of history, even if the different voices do not always sing in tune. There is a more frequent and intense dialogue between disciplines, even if on occasion it appears to be a dialogue of the deaf. The recent and apparently irresistible rise of cultural history at the expense of its neighbours may seem to contradict this trend towards polyphonization, but the contradiction, so I shall argue, is more apparent than real.

The cultural turn is in full swing. Since the year 2000, at least twelve introductions to the subject have been published, two in French - one in the famous "Que-saisje?" series, which implies a certain academic consecration
- (Ory, 2004; Poirrier, 2004); two in Spanish (Rodriguez G., 2004; Pons and Serna, 2005); two in German (Daniel, 2001; Maurer, 2008); two in English (Burke, 2004a; Green, 2007); and one each in Danish, Finnish, Italian and Brazilian Portuguese (Christiansen, 2000; Kaartinen and Korhonen, 2005; Arcangeli, 2007; Falcon, 2002). Others are on the way. An International Society for Cultural History was founded at Aberdeen in 2007 (see http://www. abdn.ac.uk/ch/ch_soc.shtml) while the French already had their own Association pour le développement de l'histoire culturelle. Conferences on the theme are becoming increasingly frequent.

Almost everything seems to be having its cultural history written these days. To quote only the titles or sub-titles of some books published since 2000, there are cultural histories of calendars (Rüpke, 2006); causality (Kern, 2004); climate (Behringer, 2007); coffee-houses (Ellis, 2004); corsets (Steele, 2001); examinations (Elman, 2000); facial hair (Peterkin, 2002); fat (Gilman, 2008); fear (by a contributor to this conference: Bourke, 2005); impotence (McLaren, 2007); insomnia (Summers-Bremner, 2007); masturbation (Laqueur, 2003); nationalism (Leerssen, 2006); pregnancy (Hanson, 2004); and tobacco (Gately, 2002). Some of these books have been written by amateurs, often journalists, but others by professional historians. The concept of "cultural revolution" has been extended from China in the 1960s, where the phrase was launched, to other places and times, including not only Russia and Mexico in the 1920s (Transchel, 2006; Vaughan and Lewis, 2006) but even the Russia of Peter the Great (Cracraft, 2004) and ancient Athens and Rome (Osborne, 2007; Habinek and Schiesaro, 1997; Wallace-Hadrill, 2008).

However, we find that recent developments are not uniform but uneven. There are national styles or traditions in cultural history (Poirrier, 2008) as in the case of anthropology or even - if to a lesser degree - in the natural sciences. These traditions illustrate yet another form of polyphony.

In Britain, for instance, we find a certain resistance to cultural history, viewed as incompatible with "hard facts" or "brass tacks" (Burke, 2008). In contrast, the USA is one of the places in which cultural history - like cultural geography and cultural anthropology - has flourished longest. It is tempting to offer cultural explanations for 
the contrast between the North American emphasis on culture and the British emphasis on society, linking the American style to the fluidity of a society of immigrants in which geographical and social mobility is high, and the British style to a more stable society as well as to what we might call a "culture of empiricism" that goes back (as far as philosophy is concerned) to John Locke or even to William of Ockham.

Again, the "global turn" in cultural history, well exemplified by Felipe Fernández-Armesto, is geographically circumscribed. The movement is, as he suggests, much stronger in the USA than it is in Europe. In any case, the majority of global historians still come from and work in the West.

Needless to say, the cultural turn by historians is a small part of a much broader movement. Within the wider academic field, we have seen the rise of Cultural Studies (including the newer domain of Visual Culture Studies), not only in Britain but elsewhere in Europe, the USA, Australia and elsewhere (Grabes, 2001). The cultural turn has affected sociology, anthropology, geography, archaeology and politics as well as the history of art, science and literature (though not always in the same way, of course, given the existence of different disciplinary traditions). Some scholars in all these disciplines now like to describe themselves as students of "culture", and even as cultural historians.

Certain domains of cultural history have attracted particular interest in recent years, including the three domains on which the conference focused: the history of representations, the history of the body and the cultural history of science, viewed here as part of a larger field that I call "the cultural history of intellectual practices".

\section{I}

A well-known essay on cultural history by Roger Chartier situated it "between practices and representations". The focus on representations has not only enlarged the territory of history but also made historians more critical of their sources by becoming more aware of mediators. Take the case of travelogues, for instance.
Thanks to traditional methods of source criticism, historians have long been aware that travelers do not offer objective descriptions of other cultures and that they often have their own agenda, religious or political. Today, however, there is more interest than there used to be about the unacknowledged contributions to these travelogues made by local informants. In other words, scholars now listen - as Bakhtin did so acutely - for different voices within a text that used to be read as a monologue. In similar fashion they have become aware of the presence of indigenous knowledge in treatises by Europeans discussing the healing properties of herbs in Asia or the New World (Grove, 1996).

Again, thanks to the dialogue between historians and specialists in literature, travelogues are now commonly viewed as examples of a literary genre with its own conventions, often following the models presented in the treatises on the "art of travel" current in early modern Europe (Stagl, 1995; Rubiès, 2000). Such conventions alerted travelers to some features of the foreign culture at the expense of discouraging them from seeing others. Over the long term they acted as obstacles to innovation, even if it was sometimes possible to surmount or circumvent these obstacles.

To such examples of the limits of representations one might add the testimony of images, which I have discussed more fully elsewhere (Burke 2001, 2008b). Images are more powerful than words, partly because they work faster, but they are also more ambiguous and liable to be understood by different viewers in ways even more diverse than the interpretation of the same text by different readers. The ambiguity is part of the power of images - but also a limitation (Barasch, 1997).

A similar point about ambiguity might be made and indeed has been made about rituals. To take one example among many possible ones, this aspect of national festivals in Venezuela has been emphasized in a recent study, suggesting that different groups of spectators interpret the same festive event in very different ways (Guss, 2000).

On the other hand, rituals, unlike texts or images, are fluid not fixed, despite attempts to fix them on the part of masters of ceremonies who like everything to be done "by the book", prout in libro meo, as Paris de Grassis, who served

ARBOR CLXXXVI 743 mayo-junio [2010] 479-486 ISSN: 0210-1963

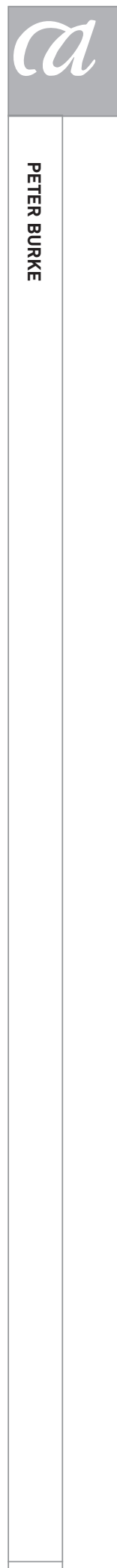

481 
Pope Julius II and kept a record of ritual events, liked to say (Burke, 1987, 177-9). Every repetition is at least slightly different from earlier ones, even if it is carried out by the same people in the same place as before.

\section{II}

Another major theme of the conference was the history of the body and the history of emotions. Since I have written elsewhere about problems in the history of the emotions (Burke, 2005), it may be more useful to concentrate on bodies. The history of the body is older than many of its practitioners think - an important contribution was made by the Brazilian historian Gilberto Freyre as early as the 1930s. He used the advertisements for runaway slaves printed in Brazilian newspapers of the early nineteenth century as a source for the reconstruction of slave bodies, noting the tribal marks on the face, the filing of the teeth, the scars left on the back from flogging and the marks left on the head and body by heavy loads (Freyre, 1937, 1963).

Today, however, studies in the history of the body proliferate, sometimes inspired by current anxieties, whether about anorexia or about obesity (Bell, 1985; Gilman 2008). This domain was well represented at the conference. However, one focus of attention in recent studies of the body which does not appear in the articles in this collection is the history of cleanliness (Vigarello, 1985; Hoy, 1995; Smith, 2006; Ashenburg, 2007). I choose it now because it is a meeting-point between studies of the body as a physical object and studies of the wider culture, between purity in the literal and in the metaphorical senses. The history of cleanliness was already studied before the rise of the New Cultural History - here as elsewhere, tribute is due to the amateur historians (Wright, 1960) who turned to certain topics before the professionals.

All the same, recent studies have had much to add, thanks to more intense research and in particular to the theories put forward by anthropologists such as the late Mary Douglas, who showed that codes of cleanliness vary from one culture to another. One theme in recent work is the importance of the frequently-enacted metaphor of cleanliness or purity - spiritual purity, ethnic cleansing, the purity of language and so on (Burke, 2004, ch.6; Biow, 2006). Another is the link between concepts of cleanliness and national identity. For example, nineteenth-century middleclass American ladies attempted to teach Italian or Polish immigrants their standards of cleanliness as part of the American way of life (Hoy, 1995, 87-121).

\section{III}

So far as the cultural history of science is concerned, it may be illuminating to locate studies of this kind within a wider field, raising the question of the relation between intellectual history, longer-established and more rigorous, and cultural history, more recently-established and more imaginative and wide-ranging. The point is not to praise either at the expense of the other but rather to draw attention to the recent interaction between these two approaches. The frontier between the two is increasingly transgressed, producing a hybrid that we might describe as the cultural history of ideas, or better, perhaps, the cultural history of intellectual practices.

To the cultural histories of science discussed elsewhere in this issue, I should like to add two examples. The first, concerned with the process of hybridization itself, is Peter Galison's study of what he calls the "subcultures" of twentieth-century physics (notably theorists and experimenters), identifying what he calls "trading zones", defined as spaces in which "two dissimilar groups can find common ground", exchanging items of information while disagreeing about the wider significance of what is exchanged (Galison, 1997, 46, 803). My second example is a recent article by James Secord (2007) on scientific conversation. It is both a contribution to the history of the communication of scientific ideas and to the rapidly expanding field of what will surely soon be named "conversation studies".

These cultural studies of science are part of a larger group, the products of a recent movement marching under the banner of "the cultural history of ideas" or more exactly, "the cultural history of intellectual practices" (Burke, 2007b). A few scholars working on the history of political thought have moved closer to cultural history thanks to their participation in the "visual turn", discussed elsewhere in this issue. Nicolai Rubinstein was a pioneer in this re- 
spect, thanks perhaps to his association with the Warburg Institute, and his interpretation of Ambrogio Lorenzetti's frescoes of good and bad government in the Palazzo Publico in Siena (Rubinstein, 1958) provoked Quentin Skinner (1986) to move away from his usual concern with classic texts and to focus on images instead. Again, José María González Garcia $(1998,2006)$ has approached political thought via the study of metaphors and visual images.

The history of reading is now an accepted approach to the history of the book. Histories of different kinds of writing, from poems circulating in manuscript (Bouza, 2001) to letters written in prison (Castillo Gómez, 2005) or techniques of note-taking (Blair, 2004) are also beginning to appear. Other historians (Head, 2003, Navarro Bonilla 2003, 2004) are focussing on the way in which governments gathered knowledge, stored it in archives and libraries and employed it for a variety of purposes.

Three important studies of the "information state" deal with the history of colonial India. One (Cohn, 1996) argues that even apparently disinterested knowledge of India was mobilized by the British to help them control the country. Another (Bayly, 1997) emphasizes the way in which, so far as information gathering or "political intelligence" was concerned, British administrators built on the work of their Mughal predecessors. The third (Dirks, 2001) claims that the caste system, at least in its modern form, was not so much an expression of Indian tradition as the product of the encounter between Indian subjects and British administrators, concerned as they were to classify the people under their control.

Another striking example of this hybrid intellectual-cultural history - an approach that would have pleased Gilberto Freyre - is what might be called the historical sociology or historical anthropology of knowledge. It is practiced, for instance, by Françoise Waquet (2003) in France, by Martin Mulsow (2007) in Germany and by William Clark (2006) in the USA. All three scholars are concerned in their different ways to link the history of ideas to broader cultural developments that include changes in the media of communication. Their concern with "cultures of knowledge" emphasizes the history of cultural practices such as reading or lecturing, the history of academic rites of passage such as examinations and degree ceremonies, and the history of the material culture of academe, including "little tools of knowledge" such as blackboards and lecterns. We normally associate the world of learning with reading and writing, but all three studies emphasize the survival of oral culture in the university in the age of print in the form of lectures, seminars and viva voce examinations.

In short, we find a body of work located on the frontier between intellectual and cultural history (understanding the term "frontier" in Peter Galison's sense as a "trading zone" rather than a line of separation).

Work of this kind makes it apparent (or more exactly, even more apparent than before) that the simple model of ideas "spreading" unchanged from one place to another is as much in need of revision as the simple model of "traditions" being handed down unchanged from one generation to another. The idea of creative "reception", long established in literary studies, is becoming commonplace among cultural and intellectual historians as well. The question whether or when, under what circumstances, a historian may describe ideas that move from one culture to another as "out of place" is currently under debate.

\section{IV}

One way to confront this question is to examine the role of translation and the way in which key ideas change in the course of being rendered into other languages. That this can happen even in the case of similar languages, such as English and German, has been neatly demonstrated by Fania Oz-Salzberger (1995) in the case of the Scottish Enlightenment thinker Adam Ferguson and his concept of "civil society", turned into bürgerliche Gesellschaft.

However, the demonstration is even clearer, not to say more dramatic, in cases in which European concepts such as liberty or democracy were translated into languages with very different structures and traditions: John Stuart Mill's Liberty into Japanese in the nineteenth century, for instance (Howland, 2001), or "democracy" into the Wolof spoken in Senegal (Schaffer, 1998). The "global turn" that Felipe Fernández-Armesto illustrates elsewhere in this issue extends to intellectual and cultural history.

ARBOR CLXXXVI 743 mayo-junio [2010] 479-486 ISSN: 0210-1963 (n) 
In these cases, of course, the problem of translation is not only linguistic but also cultural. The greater is the distance between the two cultures, between the assumptions of the original author and the new readers, the more difficult is the translator's task. In this context as in others, the anthropologist's metaphor of "cultural translation" becomes an extremely useful concept, drawing attention to the effort and skill and also to the difficult decisions involved in the act of translation.

In my view, one of the ways forward in the near future in the cultural history of ideas is precisely this concern with interlingual translation as a special case of cultural translation (Pallares-Burke, 1996; Burke, 2007a).

Living and working as we do in the age of both a cultural turn and a global turn brings us back to the question of pluralism and polyphony. What we see today is a plurality of approaches to cultural history - if not a "hundred flowers", at least a bunch - linked to a rise of international and interdisciplinary contacts that this conference illustrates in microcosmic form. To speak personally, I find this situation a welcome one, and would, indeed, extend this pluralism from regions and disciplines to periods. In other words, I would suggest that new approaches are better viewed as supplements to rather than as substitutes for old ones. Cultural history, for instance, should not drive out intellectual history, or the study of images drive out the history of texts, or the study of popular texts drive out the study of the canon, such as Cervantes or Shakespeare (though we need also to study when how and why a given canon was constructed). As in the case of cultural encounters, we should recognize the value of interaction, interpenetration and hybridization within our own discipline.

\section{BIBLIOGRAPHY}

Arcangeli, Alessandro (2007): Che cos'è la storia culturale?, Rome, Donzelli.

Ashenburg, Katherine (2007): Clean: an unsanitized history of washing, New York, Profile.

Barasch, Moshe (1997): The language of art: studies in interpretation, New York, NYU Press.

Bayly, Christopher (1997); Empire and Information: Intelligence Gathering and Social Communication in India, 17801870, Cambridge, Cambridge University Press.

Behringer, Wolfgang (2007): Kulturgeschichte des Klimas von der Eiszeit bis zur globalen Erwärmung, Munich, Beck.

Bell, Rudolf (1985): Holy Anorexia, Chicago, University of Chicago Press.

Biow, Douglas (2006): The Culture of Cleanliness in Renaissance Italy, Ithaca, Cornell University Press.

Blair, Ann (2004): "Note Taking as an Art of Transmission", Critical Inquiry 31, pp. 85-107.
Bourke, Joanna (2005): Fear: a cultural history, London, Reaktion.

Bouza, Fernando (2001): Corre manuscrito: una historia cultural del Siglo de Oro, Madrid, Marcial Pons.

Burke, Peter (1987): Historical Anthropology of Early Modern Italy: essays in perception and communication, Cambridge, Cambridge University Press.

Burke, Peter (2001): Eyewitnessing, London, Reaktion.

Burke, Peter (2004a): What is Cultural History?, $2^{\text {nd }}$ edn Cambridge, Polity Press, 2008.

Burke, Peter (2004b): Languages and Communities in Early Modern Europe, Cambridge, Cambridge University Press.

Burke, Peter (2005): "Is there a Cultural History of the Emotions?" in P. Gouk and H. Hills (eds.), Representing Emotions, Aldershot, Ashgate, pp. 35-47.

Burke, Peter (2007a): "Cultures of Translation in Early Modern Europe", in Burke and R. Po-chia Hsia (eds.), Cultural Translation in Early Modern Europe,

Aceptado: 1 de mayo de 2009 
Cambridge, Cambridge University Press, pp. 7-38.

Burke, Peter (2007b): "La historia intelectual en la era del giro cultural", Prismas 2, pp. 159-64.

Burke, Peter (2008a): "'Pas de culture, je vous prie, nous sommes britanniques': L'histoire culturelle en GrandeBretagne avant et après le tournant", in Poirrier, 15-25.

Burke, Peter (2008b): "Cómo interrogar a los testimonios visuales", in Joan Lluis Palos and Diana Carrió-Invernizzi (eds.), La historia imaginada: construcciones visuales del passado en la Edad Moderna, Barcelona, CEEH, pp. 29-40.

Carvalho Franco, Maria Sylvia de (1976) "As idéias estão no lugar", Cadernos de Debate 1, pp. 61-4.

Castillo Gómez, Antonio (2005): Entre la pluma y la pared, Madrid, Akal.

Christiansen, Palle 0. (2000): Kulturhistorie som opposition, Copenhagen, Samleren.

Clark, William (2006): Academic Charisma and the Origins of the Research University, Chicago, University of Chicago Press.

Cohn, Bernard S. (1996): Colonialism and its Forms of Knowledge: the British in India, Princeton, Princeton University Press.

Cracraft, James (2004): The Petrine revoIution in Russian culture, Cambridge, Mass., Harvard University Press.

Daniel, Ute (2001): Kompendium Kulturgeschichte, Spanish trans. Compendio de historia cultural, Madrid, Alianza, 2007.

Dirks, Nicholas (2001): Castes of Mind: CoIonialism and the Making of Modern India, Princeton, Princeton University Press.

Douglas, Mary (1966): Purity and Danger, London, Routledge.

Ellis, Markman (2004): The Coffee-House: a cultural history, London, Weidenfeld and Nicolson.
Elman, Benjamin A. (2000): A Cultural History of Civil Examinations in Late Imperial China, Berkeley, University of California Press.

Falcon, Francisco (2002): História cultural, Rio de Janeiro, Campus.

Freyre, Gilberto (1937): "Deformações de corpo dos negros fugidos", Novos Estudos Afro-Brasileiros, vol.2 (rpr Recife, Massangana 1988), pp. 243-8.

Freyre, Gilberto (1948): Ingleses no Brasil, 3rd edn, Rio de Janeiro, Topbooks, 2000.

Freyre, Gilberto (1963): O escravo nos anúncios de jornais brasileiros do século XIX: tentativa de interpretação antropológica, Recife, Imprensa Universitaria.

Galison, Peter (1997): Image and Logic: a material culture of microphysics, Chicago, University of Chicago Press.

Gately, lain (2002): Tobacco: a cultural history of how an exotic plant seduced civilization, New York, Grove Press.

Gilman, Sander L. (2008): Fat: a cultural history of obesity, Cambridge, Polity Press.

González Garcia, José (1998): Metáforas del Poder, Madrid, Alianza.

González García, José (2006): La diosa Fortuna: metamorfosis de una metáfora política, Madrid, Machado.

Grabes, Herbert (ed.) (2001): Literary History/Cultural History, Tübingen, Niemeyer.

Green, Anna (2007): Cultural History, Basingstoke, Palgrave.

Grove, Richard (1996): "Indigenous Knowledge and the Significance of Southwest India for Portuguese and Dutch Constructions of Tropical Nature", Modern Asian Studies 30, pp. 121-44.

Guss, D. M. (2000): The Festive State: Race, Ethnicity and Nationalism as Cultural Performance, Berkeley and Los Angeles, University of California Press.
Habinek, Thomas and Alessandro Schiesaro (eds.) (1997): The Roman cultural revolution, Cambridge, Cambridge University Press.

Hanson, Clare (2004): A Cultural History of Pregnancy: pregnancy, medicine and culture, 1750-2000, Basingstoke, Palgrave.

Head, Randolph (2003): "Knowing Like a State: the transformation of political knowledge in Swiss archives 14501770", Journal of Modern History 75, pp. 745-82.

Howland, Douglas (2001): Translating the West, Honolulu, University of Hawaii Press.

Hoy, Suellen (1995): Chasing Dirt: the American Pursuit of Cleanliness, New York, Oxford University Press.

Kaartinen, Marjo and Anu Korhonen (2005): Historian kirjoittamisesta, Turku, Painosalama $0 y$.

Kern, Stephen (2004): A Cultural history of Causality: science, murder novels, and systems of thought, Princeton, Princeton University Press.

Laqueur, Thomas (2003): Solitary Sex: a cultural history of masturbation, New York, Zone Books.

Leerssen, Joop (2006): National Thought in Europe: a cultural history, Amsterdam, Amsterdam University Press.

León Portilla, Miguel (ed.) (1961): Visión de los vencidos, 2nd edn, La Habana, Casa de las Américas, 1969.

McLaren, Angus (2007): Impotence: a cultural history, Chicago, University of Chicago Press.

Mantecón, Tomás (ed.) (2008): Bajtin y la historia de la cultura popular, Santander, Servicio de Publicaciones de la Universidad.

Mulsow, Martin (2007): Die unanständige Gelehrtenrepublik, Stuttgart, J. B. Metzler. 
Navarro Bonilla, Diego (2003): La imagen del archivo: representación y funciones en España (siglos XVI y XVII), Madrid, Trea.

Navarro Bonilla, Diego (2004): Escritura, Poder y Archivo: la organización documental de la Diputación del Reino de Aragón (siglos XV-XVIII), Zaragoza, Prensas Universitarias.

Osborne, Robin (ed.) (2007): Debating the Athenian Cultural Revolution: Art, literature, philosophy and politics 430 380 B.C., Cambridge, Cambridge University Press.

Oz-Salzberger, Fania (1995): Translating the Enlightenment: Scottish Civic Discourse in 18thc Germany, 0xford, Oxford University Press.

Pallares-Burke, Maria Lúcia (1996): Nísia Floresta, 0 Carapuceiro e Outros Ensaios de Tradução Cultural, São Paulo, Hucitec.

Palti, Elias José 92006): "The Problem of 'Misplaced Ideas' Revisited: Beyond the 'History of Ideas' in Latin America", Journal of the History of Ideas 67, pp. 149-79.

Peterkin, Allan (2002): One Thousand Beards: a cultural history of facial hair (New York, Arsenal Pulp Press).

Poirrier, Philippe (2004): Les enjeux de I'histoire culturelle, Paris, Seuil.

Poirrier, Philippe (ed.) (2008): L'histoire culturelle: un "tournant mondiale" dans
I'historiographie? Dijon, editions universitaires.

Pons, Anaclet and Justo Serna (2005): La historia cultural: autores, obras, lugares, Madrid, Akal.

Rodríguez Luz, Ana Luz (ed.) (2004): Pensar la cultura: los nuevos retos de la historia cultural, Medellin, Editorial Universidad de Antioquia.

Rubiès, Joan-Pau (2000): "Travel Writing as a Genre", Journeys 1, pp. 5-33.

Rubinstein, Nicolai (1958): "Political Ideas in Sienese Art", Journal of the Warburg and Courtauld Institutes, 21, pp. 179-207.

Rüpke, Jörg (2006): Zeit und Fest: Eine Kulturgeschichte des Kalendars, Munich, Beck.

Schaffer, Frederick (1998): Democracy in Translation: understanding politics in an unfamiliar culture, Ithaca, Cornell University Press.

Schwarz, Roberto (1977): Ao Vencedor as Batatas, São Paulo, Editora 34.

Secord, James A. (2007): "How Scientific Conversation became Shop Talk", Transactions of the Royal Historical Society 17, pp. 129-56.

Skinner, Quentin (1986): "Ambrogio Lorenzetti: the Artist as Political Philosopher", Proceedings of the British Academy, 72, pp. 1-56.

Smith, Virginia (2006): Clean: a history of personal hygiene and purity, Oxford, Oxford University Press.
Stagl, Justin (1995): A History of Curiosity: the Theory of Travel, 1550-1800, London, Routledge.

Steele, Valerie (2001): The Corset: a cultural history, New Haven, Yale University Press.

Summers-Bremner, Eluned (2007): Insomnia: a cultural history, London, Reaktion.

Transchel, Kate (2006): Under the influence: working-class drinking, temperance, and cultural revolution in Russia, 1895-1932, Pittsburgh, University of Pittsburgh Press.

Vaughan, Mary K. and Stephen E. Lewis (eds.) (2006): The Eagle and the Virgin: nation and cultural revolution in Mexico, 1920-1940, Durham. NC, Duke University Press.

Vigarello, Georges (1985): Le propre et le sale, Paris, Seuil.

Wachtel, Nathan (1971): La vision des vaincus, Paris, Gallimard.

Wallace-Hadrill, Andrew (2008): Rome's Cultural Revolution, Cambridge, Cambridge University Press.

Waquet, Françoise (2003): Parler comme un livre: l'oralité et le savoir, 16e-20e siècle, Paris, Albin Michel.

Wrangham, Richard et al. (eds.) (1994): Chimpanzee Cultures, Cambridge, Mass., Harvard University Press.

Wright, Lawrence (1960): Clean and Decent: the fascinating history of the bathroom and the water closet, London, Routledge. 